\title{
A Temperature-Independent Cold-Shock Protein Homolog Acts as a Virulence Factor in Xylella fastidiosa
}

\author{
Lindsey P. Burbank and Drake C. Stenger \\ Agricultural Research Service, United States Department of Agriculture, San Joaquin Valley Agricultural Sciences Center, 9611 \\ South Riverbend Ave, Parlier, CA 93648-9757, U.S.A.
}

Submitted 24 November 2015. Accepted 17 January 2016.

\begin{abstract}
Xylella fastidiosa, causal agent of Pierce's disease (PD) of grapevine, is a fastidious organism that requires very specific conditions for replication and plant colonization. Cold temperatures reduce growth and survival of $X$. fastidiosa both in vitro and in planta. However, little is known regarding physiological responses of $X$. fastidiosa to temperature changes. Cold-shock proteins (CSP), a family of nucleic acid-binding proteins, act as chaperones facilitating translation at low temperatures. Bacterial genomes often encode multiple CSP, some of which are strongly induced following exposure to cold. Additionally, CSP contribute to the general stress response through mRNA stabilization and posttranscriptional regulation. A putative CSP homolog (Csp1) with RNA-binding activity was identified in $X$. fastidiosa Stag's Leap. The csp1 gene lacked the long $5^{\prime}$ untranslated region characteristic of cold-inducible genes and was expressed in a temperature-independent manner. As compared with the wild type, a deletion mutant of $\operatorname{csp1}(\Delta \operatorname{csp} 1)$ had decreased survival rates following cold exposure and salt stress in vitro. The deletion mutant also was significantly less virulent in grapevine, as compared with the wild type, in the absence of cold stress. These results suggest an important function of $X$. fastidiosa Csp1 in response to cellular stress and during plant colonization.
\end{abstract}

The bacterial pathogen Xylella fastidiosa infects multiple hosts, including several important crop and landscape plants. $X$. fastidiosa colonizes xylem tissue, resulting in characteristic leaf scorch symptoms, often leading to decline or death of the plant (Hopkins and Purcell 2002; Purcell et al. 1999). X. fastidiosa subsp. fastidiosa infection of grapevine, causing Pierce's disease (PD), is mainly prevalent in subtropical climates and, historically, has had a devastating impact on the grape industry in California (Hopkins and Purcell 2002). Bacterial temperature response likely plays a role in pathogenesis of $\mathrm{PD}$, as virulence-associated genes are upregulated in $X$. fastidiosa after exposure to heat and cold conditions are correlated with reduced persistence of PD in grapevine (Feil and Purcell 2001; Koide et al. 2006; Lieth et al. 2011; Meyer 2010). However, little is known regarding temperature acclimation mechanisms of $X$. fastidiosa during plant infection.

Optimal replication of $X$. fastidiosa occurs at $28^{\circ} \mathrm{C}$, under laboratory conditions. Restricted growth and loss of viability have been observed for $X$. fastidiosa cultivated at lower temperatures in vitro (Feil and Purcell 2001; Meyer 2010). A crucial and highly

Corresponding author: L. P. Burbank;

E-mail: lindsey.burbank@ars.usda.gov

This article is in the public domain and not copyrightable. It may be freely reprinted with customary crediting of the source. The American Phytopathological Society, 2016. conserved aspect of bacterial adaptation to cold temperatures is the production of cold-shock proteins (CSP), a large number of which belong to the CspA family of nucleic acid-binding proteins and are strongly induced by temperature change (Etchegaray and Inouye 1999; Graumann and Marahiel 1998; Graumann et al. 1997; Lee et al. 1994; Yamanaka et al. 1998). In addition to being highly conserved in prokaryotes, bacterial CSP also are remarkably similar to eukaryotic cold-shock domain proteins, many of which are involved in cold-shock response and drought tolerance in plants (Kim et al. 2013; Nakaminami et al. 2006; Schröder et al. 1995). CspA family proteins facilitate transcription and translation at low temperatures by acting as chaperones to prevent the formation of RNA secondary structure as well as in a regulatory capacity to stabilize specific mRNA molecules (Bae et al. 2000; CohenOr et al. 2010; Jiang et al. 1997; Nakaminami et al. 2006; Schindelin et al. 1993). Cold-inducible gene expression is often the result of posttranscriptional regulation, involving an unusually long $5^{\prime}$ untranslated region (UTR) (Janiyani and Ray 2002; Jiang et al. 1996; Kaan et al. 1999). In Escherichia coli at $37^{\circ} \mathrm{C}$, the 160 -nt $\operatorname{csp} A 5^{\prime}$ UTR interacts with a portion of the coding region, obstructing the ribosomal binding site (Breaker 2010; Giuliodori et al. 2010). At lower temperatures, a series of stem loop structures are formed within the 5' UTR, allowing uninhibited access to the ribosomal binding site and coding region (Giuliodori et al. 2010). This mechanism facilitates cold-inducible expression of CSP and allows for adaptation of bacterial cells to cold temperatures. A number of cold-inducible genes are characterized by similar 5' UTR sequences of 150 to $200 \mathrm{nt}$ in length (Jiang et al. 1996; Mitta et al. 1997; Nakashima et al. 1996; Wang et al. 1999). However, other mechanisms of cold-dependent regulation, such as E. coli $\mathrm{CspE}$ and Salmonella enterica $\mathrm{CspH}$, which have shorter 5' UTR sequences, are attributed to differential stability of mRNA at different temperatures (Kim et al. 2001; Uppal et al. 2008).

In addition to cold adaptation, there also is evidence that CSP are involved in other aspects of bacterial survival and virulence. Induction of CSP can increase survival under conditions of osmotic or oxidative stress as well as during stationary phase (Balhesteros et al. 2010; Kandror et al. 2002; Loepfe et al. 2010; Michaux et al. 2012; Schmid et al. 2009). Plant pathogens often encounter reactive oxygen species (ROS) during infection of the host, as a result of the immune response or cell lysis (Burbank and Roper 2014; Flores-Cruz and Allen 2011; Fones and Preston 2012). Production of ROS increases when plants are subjected to pathogen invasion or abiotic stress such as temperature extremes (Lamb and Dixon 1997; Wise 1995). Additionally, numerous changes in the host plant following cold stress, including elevated levels of abscisic acid and phenolic compounds in xylem sap (Król et al. 2015; Meyer and Kirkpatrick 
2011; Wilhelm et al. 2011), may be another challenge to successful infection of $X$. fastidios $a$ under these conditions. A demonstrated role of CSP as virulence factors has been limited to animal pathogens and has been linked to stress adaptation during intracellular colonization (Loepfe et al. 2010; Michaux et al. 2012; Wang et al. 2014). We chose to investigate the role of a representative $X$. fastidiosa CSP homolog in response to cold, cellular stress conditions, and during plant infection to elucidate the role of this protein in $X$. fastidiosa survival, replication, and development of PD.

\section{RESULTS}

\section{$X$. fastidiosa encodes a CspA homolog.}

In X. fastidiosa subsp. fastidiosa, a homolog of CspA was identified (Csp1, encoded by cspl [PD1380]) that shares 53\% amino acid sequence identity with the major CSP (CspA) from E. coli K-12 (ECDH10B_3735) and 52\% identity with a CspA homolog (XC_1828) from Xanthomonas campestris pv. campestris (Fig. 1A) (Dehal et al. 2010; Marchler-Bauer et al. 2013). Among different subspecies of $X$. fastidiosa, the Csp 1 sequence is highly conserved. The Csp1 protein of the $X$. fastidiosa strain Stag's Leap shares $100 \%$ amino acid sequence identity with CSP homologs in strains Temecula-1 and M23 (subsp. fastidiosa), M12 (subsp. multiplex), and Ann-1 (subsp. sandyi) and shares 97\% amino acid identity with a CSP homolog from strain 9a5c (subsp. pauca) (Dehal et al. 2010; Marchler-Bauer et al. 2013) (Fig. 1B). Conserved nucleic acid-binding domains characteristic of CspA superfamily proteins (Marchler-Bauer et al. 2013; Weber et al. 2002) are retained in Csp1 homologs of all four $X$. fastidiosa subspecies (Fig. 1B). A second CspA homolog also is present in the $X$. fastidiosa genome (Csp2, encoded by csp2 [PD1993]). However, as a viable knockout mutant could not be obtained, characterization of $\operatorname{csp} 2$ is reserved for further study.

\section{$X$. fastidiosa Csp1 is important for in vitro cold tolerance.}

A knockout mutant of $X$. fastidiosa cspl ( $\Delta \operatorname{cspl}$ ) was constructed to study the function of Csp1 in $X$. fastidiosa Stag's Leap. Wild-type Stag's Leap and $\Delta$ cspl were tested for survival after exposure cold $\left(4^{\circ} \mathrm{C}\right)$ in vitro. Percent survival was determined based on number of CFU before and after cold treatment of cell suspensions in $1 \times$ phosphate buffered saline (PBS) for $24 \mathrm{~h}$ at $4^{\circ} \mathrm{C}$ (Fig. 2). The deletion mutant had significantly reduced survival $(7 \%)$ as compared with the wild type (66\%) (Fig. 2A). Complementation of $\Delta c s p l$ by chromosomal insertion of a wild-type copy of $X$. fastidiosa cspl at a neutral location, using the method of Matsumoto et al. (2009), restored mean survival rate to $74 \%$ (Fig. 2A), showing that $X$. fastidiosa $\mathrm{Csp} 1$ contributes to survival at low temperature. In addition, complementation with CspA homologs from $E$. coli and Xanthomonas campestris pv. campestris also restored cold survival in $\Delta \operatorname{cspl}$ to $54 \%$ and $60 \%$, respectively (Fig. 2A). These results suggest that the function of $X$. fastidios $a$ Csp 1 is conserved with CspA homologs of other bacterial species. Insertion of $X$. fastidiosa csp 1, E. coli cspA, or Xanthomonas campestris pv. campestris cspA into a neutral chromosomal region of wild-type Stag's Leap did not significantly increase cold tolerance, as quantified by percent survival after $24 \mathrm{~h}$ at $4^{\circ} \mathrm{C}$ (Fig. 2B), confirming that differences in CSP activity between different species do not account for the cold sensitivity of $X$. fastidiosa. It appears that cold response in $X$. fastidiosa is at least partially dependent on Csp1 in vitro.

\section{$X$. fastidiosa Csp1 contributes to salt stress tolerance but not oxidative stress tolerance in vitro.}

It was relevant to determine if $X$. fastidiosa Csp1 was involved in survival under stress conditions other than cold. As compared with wild-type $X$. fastidios $a$ Stag's Leap, which had a survival rate of $67 \%, \Delta \operatorname{csp} 1$ had decreased survival $(9 \%)$ following incubation in a concentrated salt solution $(0.3 \mathrm{M} \mathrm{NaCl})$ for $1 \mathrm{~h}$ (Fig. 3). Survival of the complemented strain $\Delta \operatorname{csp} / \operatorname{csp} 1^{+}$ $(46 \%)$ did not significantly differ from the wild type (Fig. 3). Incubation in either $0.1 \mathrm{M} \mathrm{NaCl}$ or $0.05 \mathrm{M} \mathrm{NaCl}$ after 48 or $72 \mathrm{~h}$, respectively, also resulted in decreased survival of $\Delta \operatorname{csp} 1$ as compared with wild type (data not shown). Because CSP can, in some cases, contribute to bacterial resistance to oxidative stress (Loepfe et al. 2010; Wang et al. 2014), hydrogen peroxide sensitivity was quantified, using a disc inhibition assay (Matsumoto et al. 2009). However, the inhibition zone radius was not significantly different for $\Delta c s p l$ as compared with wild-type Stag's Leap, indicating that Csp1 is most likely not part of the response to peroxide stress (data not shown).

\section{$X$. fastidiosa Csp1 binds single-stranded RNA.}

$X$. fastidiosa Csp1 was expressed in and purified from E. coli for characterization of protein function. RNA binding activity was determined by electrophoretic mobility shift assay, using labeled single-stranded RNA probes of 100 bases in length (Fig. 4). The observed band shift that occurred with the addition of higher concentrations of Csp1 demonstrated binding activity. No band shift was observed using bovine serum albumin as a non-RNA binding protein control (Fig. 4). This result is
A

\author{
X. fastidiosa \\ $X$. campestris \\ E. coli
}

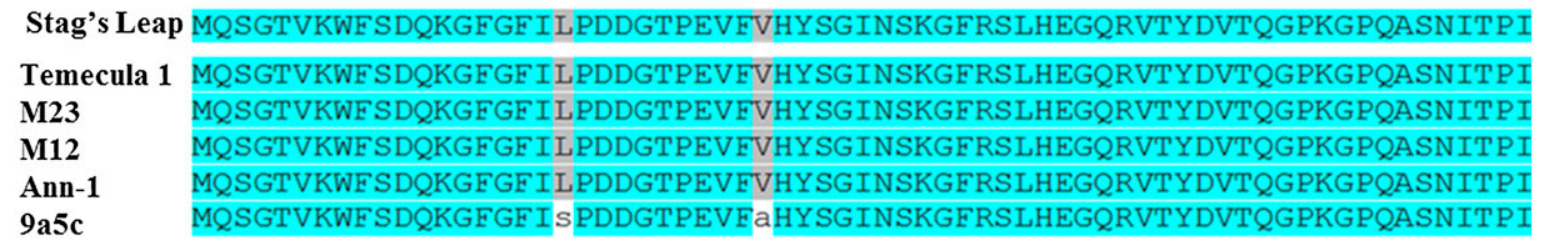

Fig. 1. Csp1 is a cold shock protein homolog encoded by Xylella fastidiosa. A, Multiple sequence alignment of protein sequences comparing homologs from different bacterial species and B, different $X$. fastidiosa strains. Protein sequences were obtained from the MicrobesOnline database (Dehal et al. 2010) and alignment was performed using Clustal Omega (Sievers et al. 2011). Nucleic acid binding domains were identified using the Conserved Domain Database (Marchler-Bauer et al. 2013). 
consistent with a potential role of $X$. fastidiosa Csp1 in stabilizing translation at low temperatures by altering secondary structure in single-stranded RNA.

\section{Short 5' UTR of X. fastidiosa csp1}

does not facilitate cold-inducible expression.

The 5' UTR region of $X$. fastidiosa cspl mRNA was amplified and sequenced by $5^{\prime}$ RACE (rapid amplification of cDNA ends) to determine its potential role as a cold-inducible regulatory element (Fig. 5). The 5' UTR of $X$. fastidiosa cspl was $54 \mathrm{nt}$ in length, shorter than expected for cold-inducible regulation. To quantify expression relative to temperature, a reporter

A

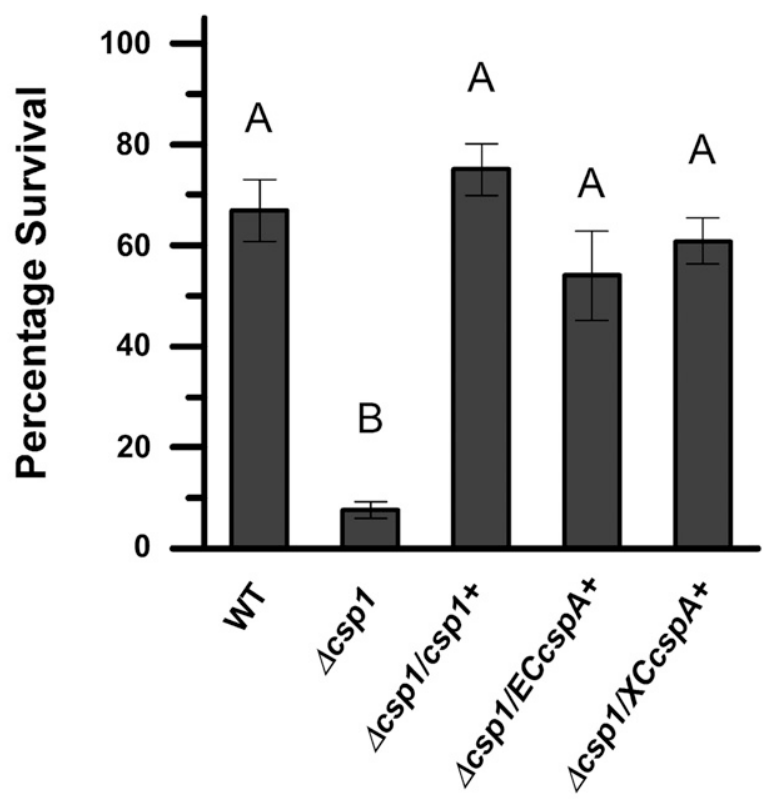

B

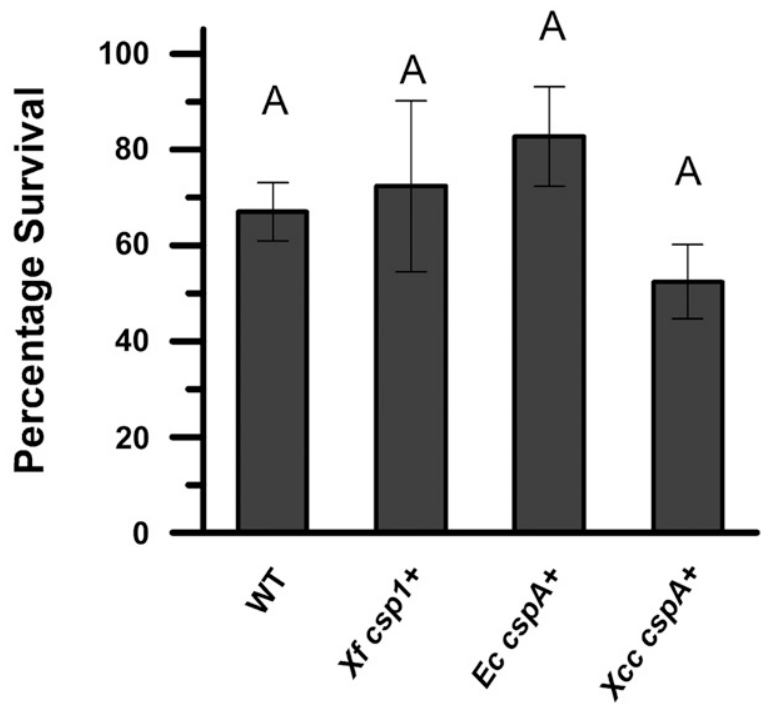

Fig. 2. Cold tolerance of $\Delta$ csp1. Percent cell survival of Xylella fastidiosa was quantified based on counts of CFU before and after $24 \mathrm{~h}$ at $4{ }^{\circ} \mathrm{C}$. A, Mean percent cell survival of wild type (WT), a deletion mutant of $\operatorname{cspl} 1$ $(\Delta \operatorname{csp} 1)$, and $\Delta \operatorname{cspl} 1$ complemented with $\operatorname{csp} 1$ from $X$. fastidiosa $\left(\Delta \operatorname{csp} 1 / \operatorname{csp} 1^{+}\right)$ or $\operatorname{csp} A$ of Escherichia coli $(\Delta \operatorname{csp} 1 / E \operatorname{ccsp} A)$. B, Mean percent cell survival of WT and $X$. fastidiosa strains with a second copy of the cold shock protein homolog from $X$. fastidiosa $\left(X f \operatorname{csp} 1^{+}\right)$, E. coli $(E c \operatorname{csp} A)$, or Xanthomonas campestris pv. campestris $\left(X c c c s p^{+}\right)$. Bars represent means ( \pm standard error) combined from three independent experiments, each consisting of three replicates plated in duplicate. Means with different letters are significantly different based on analysis of variance followed by a TukeyKramer multiple comparison test $(\alpha=0.05)$. construct in $\mathrm{pCR} 8 / \mathrm{GW} / \mathrm{TOPO}$ was created by fusing the luciferase open reading frame (ORF) $3^{\prime}$ proximal to the $X$. fastidiosa cspl ORF. The resulting construct (pCR8-Xfcsp1-luc) retained the $X$. fastidiosa csp1 5' UTR. A similar luciferase reporter construct (pCR8-ECcspA-luc) was made using E. coli $\operatorname{cspA}$ (including the $5^{\prime}$ UTR) as a cold-inducible control. CSP ORF sequences were included in reporter constructs, as sequences downstream of the start codon, known as the downstream box, are important for cold-inducible expression (Mitta et al. 1997). E. coli recombinants bearing reporter plasmids pCR8-Xfcsp1luc and pCR8-ECcspA-luc were transferred from 37 to $15^{\circ} \mathrm{C}$

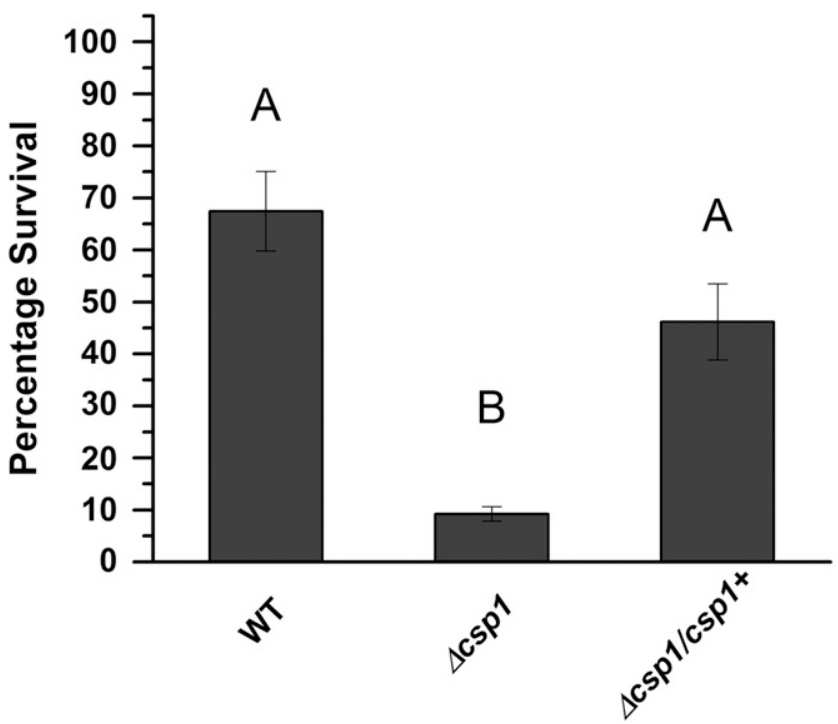

Fig. 3. Osmotic stress tolerance of $\Delta$ cspl. Percent survival of $X$. fastidiosa was quantified based on counts of CFU before and after incubation in $0.3 \mathrm{M}$ $\mathrm{NaCl}$ for $1 \mathrm{~h}$, and the mean percent survival of wild type (WT), a deletion mutant of $\operatorname{cspl}(\Delta \operatorname{cspl})$, and $\Delta \operatorname{cspl}$ complemented with $\operatorname{cspl}$ from $X$. fastidiosa $\left(\Delta \operatorname{cspl} / \operatorname{cspl} 1^{+}\right)$is shown. Bars represent means ( \pm standard error) combined from three independent experiments, each consisting of three replicates plated in duplicate. Means with different letters are significantly different based on analysis of variance followed by a Tukey-Kramer multiple comparison test $(\alpha=0.05)$.

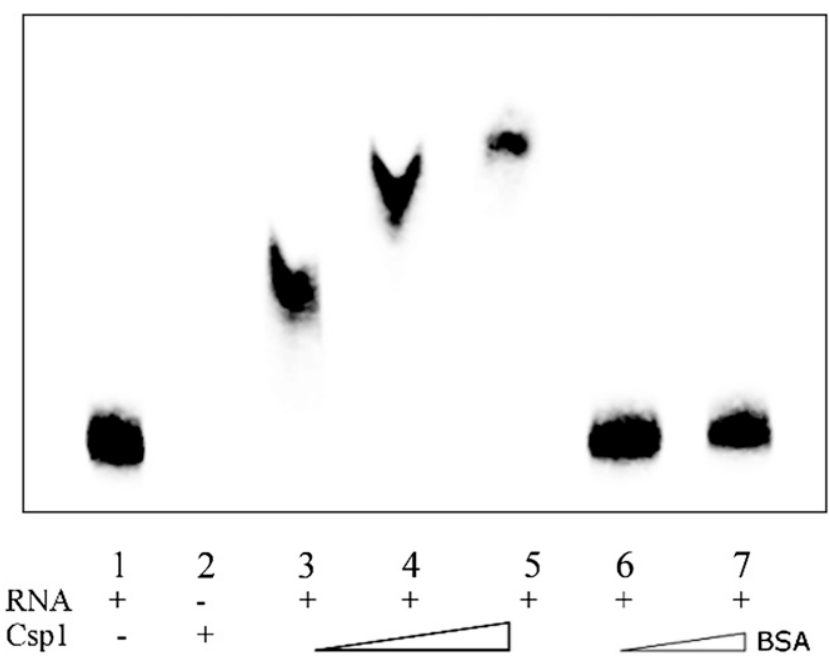

Fig. 4. RNA-binding activity of Csp1. Purified X. fastidiosa Csp1 was used to determine RNA-binding activity, using an electrophoretic mobility shift assay. Reduced electrophoretic mobility of single-stranded RNA probes with the addition of Csp1 indicates binding activity. Binding reactions contained $20 \mathrm{ng}$ of biotin-labeled RNA and increasing concentrations of purified Csp1-His $(1,3$, and $5 \mu \mathrm{g})$. Bovine serum albumin $(5$ or $10 \mu \mathrm{g})$ was used as a nonbinding protein control. 
and luciferase protein expression was quantified by Western blot (Fig. 6). Expression of luciferase from pCR8-ECcspA-luc was induced after temperature drop and showed increasing levels over the course of $2 \mathrm{~h}$ at $15^{\circ} \mathrm{C}$ (Fig. 6). In contrast, luciferase expression from pCR8-Xfcsp1-luc was constitutive in relation to temperature (Fig. 6). Based on this evidence, it appears that $X$. fastidiosa Csp1 is not cold-inducible through the function of its $5^{\prime}$ leader RNA. To address the possibility of $X$. fastidiosa-specific regulatory elements, the Xfcsp1-luc reporter construct also was inserted into the broad-host range plasmid pBBR1-MCS5 (replication competent in X. fastidiosa) and was transformed into wild-type Stag's Leap. Reporter expression in $X$. fastidiosa was not increased by temperature shift to $15^{\circ} \mathrm{C}$ (data not shown), confirming that $X$. fastidiosa Csp 1 expression is regulated in a temperature-independent manner.

\section{Csp1 is required for full virulence in grapevine.}

There is little or no evidence for a role of CSP in virulence of plant pathogens. To evaluate the role of $X$. fastidiosa $\mathrm{Csp} 1$ in the infection process, susceptible Vitis vinifera (Chardonnay) plants were inoculated with wild-type $X$. fastidiosa Stag's Leap, $\Delta \operatorname{cspl}$, and $\Delta \operatorname{csp} / \operatorname{cspl}^{+}$and were observed for symptom development at 12 weeks postinoculation (Fig. 7A and B). Severity of disease symptoms was rated based on the 0 to 5 scoring system by Guilhabert and Kirkpatrick (2005) (Fig. 7B). The mean disease score of $\Delta c s p l$-inoculated vines was significantly reduced in comparison with wild type-inoculated plants (Fig. 7B). Plants inoculated with $\Delta \operatorname{csp} / c s p I^{+}$showed symptoms similar to wild type-inoculateded plants. As inoculated plants were grown in a temperature-controlled greenhouse during the summer, this reduction in virulence was not due to cold stress. In addition to visible disease symptoms, bacterial titer in planta was quantified by quantitative polymerase chain reaction (qPCR), using total DNA extracted from petioles taken from $15 \mathrm{~cm}$ above the point of inoculation (Fig. 8). X. fastidiosa DNA quantity was significantly lower in $\Delta \operatorname{csp} 1$-inoculated plants compared with wild type-infected vines. Partial complementation of bacterial DNA quantity was observed in plants inoculated with $\Delta \operatorname{csp} / \operatorname{csp} I^{+}$(Fig. 8). These results indicate that $X$. fastidiosa $\mathrm{Csp} 1$ is a virulence factor important for colonization of the plant host in the absence of cold stress.

To address the question of whether Csp1 also is important for cold survival in planta, inoculated grapevines were separated

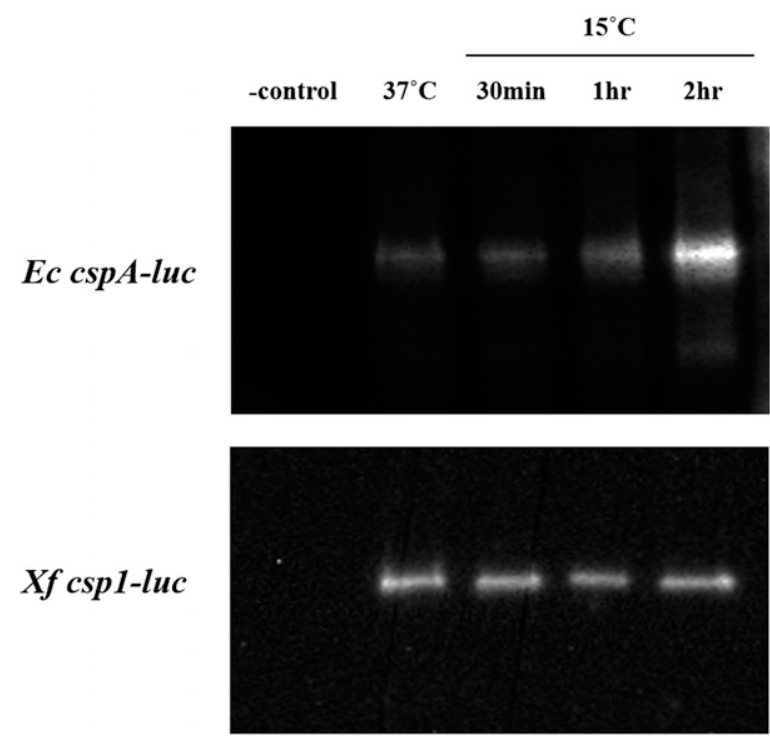

Fig. 6. Temperature-independent expression of Xylella fastidiosa Csp1. Luciferase reporter expression of constructs in Escherichia coli bearing the $l u c$ open reading frame (ORF) fused 3 '-proximal to E. coli cspA (Ec cspA$l u c$ ) or $X$. fastidiosa cspl ( $X f$ csp1-luc) ORF. Each construct included the native promoter and $5^{\prime}$ intranslated region of the respective bacterial species. Cultures were grown at $37^{\circ} \mathrm{C}$ and were shifted to $15^{\circ} \mathrm{C}$ to evaluate induction upon exposure to cold. Total protein samples $(1 \mu \mathrm{g})$ were extracted before or after (30 min, $1 \mathrm{~h}$, and $2 \mathrm{~h}$ ) temperature shift; luciferase was detected following sodium dodecyl sulfate-polyacrylamide gel electrophoresis and Western blotting with a firefly luciferase monoclonal antibody. A construct bearing only the luc ORF with no promoter served as a negative control (-control).

\author{
A \\ $X f \operatorname{csp} 1$ \\ 5' GUGCGCUAGGG GACGUACA UUACUCAUUUCAAUUUGAAAAGGUCUCGCAUCACC 3' \\ Ec $\operatorname{csp} A$ \\ 5'AUCAACGGUUUGACGUACAGACCAUUAAAGCAGUGUAGUAAGGCAAGUCCCUUCAAGAGUUAUCGU \\ UGACCCCUCGUAGUGCACAUUCCUUUAACGCUUCAAAAUCUGUAAAGCACGCCAUAUCGCCGAAAGG \\ CACACUUAAUUAUUAAAGGUAAUACACU 3'
}

B E. coli $\operatorname{csp} A$

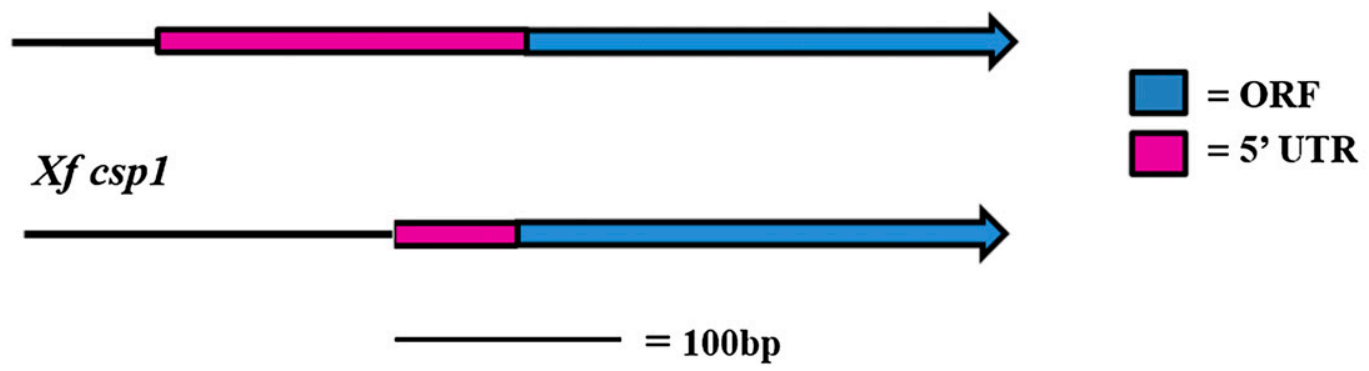

Fig. 5. Xylella fastidiosa csp1 has a short $5^{\prime}$ untranslated region (UTR). A, Sequence of the $5^{\prime}$ UTR of X. fastidiosa csp1 and of Escherichia coli cspA. B, Schematic representation of $5^{\prime}$ UTR of $X$. fastidios $a$ and of $E$. coli cold-shock homolog genes. The mRNA $5^{\prime}$ terminus of each was determined by sequencing cloned 5' rapid amplification of cDNA end products. 
into two separate treatments, a control group that remained in a greenhouse at or above $25^{\circ} \mathrm{C}$ and a cold-treated group that was placed in a cold chamber at $4^{\circ} \mathrm{C}$. Both treatments were under reduced light to promote dormancy. Each treatment contained at least 20 plants per strain inoculated. After 6 weeks of cold treatment, all the grapevines were returned to the greenhouse and were placed under a 10-h daylight cycle to grow out, for evaluation of $X$. fastidios $a$ persistence. After 6 weeks of regrowth, bacterial titer was determined by qPCR. In wild type-inoculated plants, the titer of $X$. fastidiosa was reduced $36 \%$ in the coldtreated samples compared with the untreated controls. In $\Delta$ csplinoculated plants, there was a $40 \%$ reduction in bacterial titer in cold-treated plants, which was not significantly different from the wild type. These results suggest that the contribution of Csp1 to $X$. fastidiosa cold tolerance in planta is minimal.

\section{DISCUSSION}

$X$. fastidiosa is a fastidious bacterium, requiring very specific conditions for optimal growth and replication. $X$. fastidiosa does not replicate at or below $12^{\circ} \mathrm{C}$ and, in many cases, shows

\section{A}

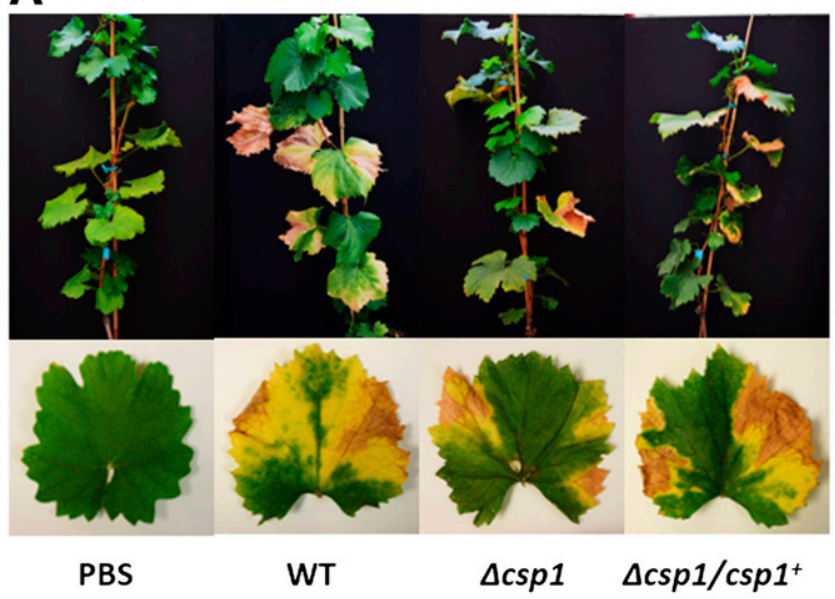

B

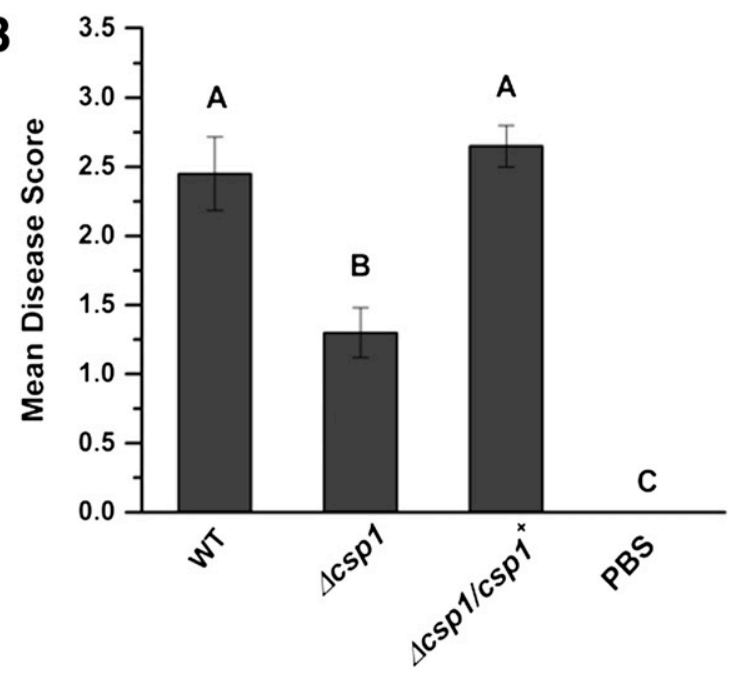

Fig. 7. Xylella fastidiosa $\Delta$ csp1 has reduced virulence in grapevine. Susceptible grapevines (Vitis vinifera $\mathrm{cv}$. Chardonnay) were needle-inoculated with wild-type Stag's Leap (WT), a csp1 deletion mutant ( $\Delta$ cspl), or the complemented deletion mutant $\left(\Delta c s p / c s p^{+}\right)$. Plants inoculated with phosphate buffered saline served as negative controls. A, Symptom development 12 weeks postinoculation. B, Disease rating based on the 0 to 5 rating system by Roper et al. (2007). Bars represent means ( \pm standard error); means with different letters are significantly different based on analysis of variance followed by a Tukey-Kramer multiple comparison test $(\alpha=0.05)$. rapid loss of viability at $5^{\circ} \mathrm{C}$ (Feil and Purcell 2001). In contrast, many plant-pathogenic bacteria are able to consistently withstand a much greater range of temperatures both in vitro and in planta (Feil and Purcell 2001; Smirnova et al. 2001). The narrow range of temperatures conducive to growth and survival of $X$. fastidiosa in vitro suggests a limited ability to adapt to temperature fluctuations.

Cold exposure in mesophilic bacteria leads to disruption of transcription and translation, loss of membrane integrity, and disruption of cell metabolism (Cao-Hoang et al. 2010; Phadtare 2011; Phadtare and Severinov 2010). The severe impact of cold stress on bacterial cells has led to an evolved cold response, often including CSP with similar or overlapping function. In E. coli, nine different CSP (CspA to CspI) are expressed in response to cold stress, environmental changes, or the transition to stationary phase (Goldstein et al. 1990). Cold shock-induced expression of CSP is often substantial; CspA alone becomes up to $10 \%$ of the total cellular protein of $E$. coli at $15^{\circ} \mathrm{C}$ (Goldstein et al. 1990). Three CspA homologs in Bacillis subtilis are induced transiently after a temperature shift from 37 to $15^{\circ} \mathrm{C}$ and are important for optimal protein synthesis (Graumann et al. 1996, 1997). Similarly, Listeria monocytogenes CspA and CspD are dispensable for growth at $37^{\circ} \mathrm{C}$ but necessary for replication at lower temperatures (Schmid et al. 2009). In species with several CSP homologs, mutagenesis studies have demonstrated that multiple gene knockouts are necessary to see a reduction in cold-shock survival but that loss of all CSP at once is often lethal (Graumann et al. 1997; Schmid et al. 2009; Xia et al. 2001).

Certain members of the CSP family are temperatureindependent, such as E. coli $\mathrm{CspC}$ and $\mathrm{CspE}$, which are expressed constitutively at $37^{\circ} \mathrm{C}$ and are involved in regulation of the general stress response (Shenhar et al. 2012), or CspD, which is growth-phase dependent (Yamanaka and Inouye 1997). Expression of Listeria monocytogenes CspA and CspD are induced by high salt concentrations and at least one CSP is necessary for

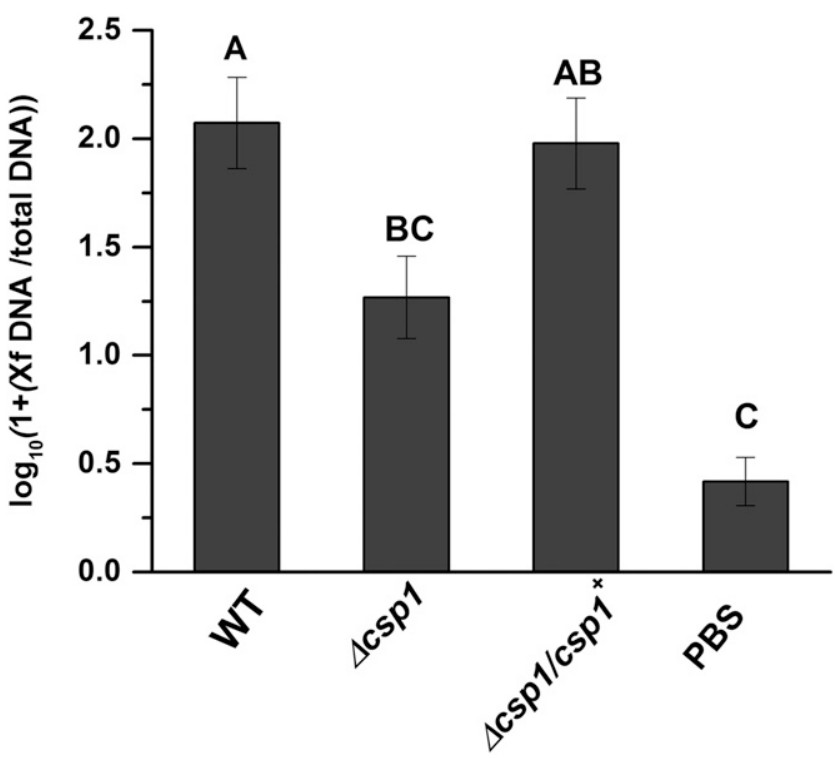

Fig. 8. Xylella fastidiosa $\Delta$ cspl has lower bacterial titer in planta. Susceptible grapevines (Vitis vinifera $\mathrm{cv}$. Chardonnay) were needle-inoculated with wild-type Stag's Leap (WT), a cspl deletion mutant $(\Delta \operatorname{csp} 1)$ or the complemented deletion mutant $\left(\Delta \operatorname{csp} / \operatorname{csp}^{+}\right)$. Plants inoculated with phosphate buffered saline served as negative controls. Bacterial titer was determined by quantitative polymerase chain reaction 12 weeks postinoculation. Quantity of $X$. fastidiosa DNA was determined based on a standard curve of wild-type Stag's Leap genomic DNA and was normalized to total DNA concentration. Bars represent means ( \pm standard error); means with different letters are significantly different based on analysis of variance followed by a TukeyKramer multiple comparison test $(\alpha=0.05)$. 
osmotic-stress tolerance (Schmid et al. 2009). Clostridium botulinum also requires a set of CSP for survival and growth when exposed to high $\mathrm{NaCl}$ concentrations, low $\mathrm{pH}$, or ethanol, in addition to cold stress (Derman et al. 2015; Söderholm et al. 2011). We found that $X$. fastidiosa Csp1 was important for survival of osmotic stress by exposure to $0.3 \mathrm{M} \mathrm{NaCl}$, suggesting a role in certain aspects of environmental adaptation beyond coldshock response. Although this salt concentration is higher than what would be encountered during plant colonization, experiments conducted with lower salt concentrations produced similar results, albeit over a longer timeframe (data not shown).

Accumulation of ROS is another component of temperature acclimation in plants as part of the stress-response signaling pathway (Chinnusamy et al. 2010); and in bacterial cells, CSP can be important for oxidative-stress defense (Chattopadhyay et al. 2011; Loepfe et al. 2010). However, sensitivity of X. fastidiosa to hydrogen peroxide was not affected by loss of Csp1. This may be due to predominance of the inducible oxidative-stress response, which includes production of detoxifying enzymes (Matsumoto et al. 2009), or the presence of other protective proteins, possibly a role of a second CSP, Csp2. Although some level of ROS are produced in xylem tissue (Barceló 1998), it is also possible that $X$. fastidiosa does not normally encounter the same magnitude of ROS, due to its specific habitat, and does not necessarily require the same level of oxidative-stress defense as other plant pathogens. However, it is demonstrated overall that Csp1 contributes to survival of $X$. fastidiosa under certain stress conditions in vitro.

Reporter expression indicated that $X$. fastidiosa $C s p 1$ is not induced by a drop in temperature in vitro. It is likely that Csp1 is regulated in a manner similar to temperature-independent CSP, E. coli CspC and CspE (Phadtare and Inouye 2001; Shenhar et al. 2012). X. fastidiosa does not appear to have the highly redundant inducible cold-shock response found in many cold-adapted bacterial species, perhaps due to its reduced genome and the specific niche colonized. X. fastidiosa encodes only two CspA family homologs in its genome. These two proteins alone may be responsible for both an inducible cold response and the other observed stress survival functions of CSP studied in other systems. Multiple attempts to create a knockout mutant in the second $X$. fastidiosa CSP (Csp2) were unsuccessful, suggesting lethality or a significant loss of fitness. In light of our findings that $X$. fastidiosa Csp1 is expressed independent of temperature, it is possible that Csp2 is more important for an inducible cold-shock response and for cold survival in planta. Furthermore, less redundancy in the cold-shock response may contribute to inherent sensitivity of $X$. fastidiosa to low temperatures.

In a number of animal pathogens, CSP are important for survival during host invasion as well as regulation of specific virulence-associated proteins (Erova et al. 2008; Loepfe et al. 2010; Michaux et al. 2012; Wang et al. 2014). Previously, no evidence for a specific role of CSP in plant infection was available, in spite of the fact that several plant-pathogenic bacterial species possess cold-induced virulence factors (Budde et al. 1998; Wei et al. 1992). Notably, $\Delta \operatorname{cspl}$ was less virulent in grapevine under summer growing conditions without being subjected to cold stress. Reduced bacterial populations observed in $\Delta$ cspl-inoculated grapevines support the hypothetical role of Csp1 in stress survival during plant infection. However, this does not rule out a potential role of $X$. fastidiosa Csp1 in virulenceassociated gene regulation through RNA binding activity.

\section{MATERIALS AND METHODS}

Bacterial strains and culture conditions.

All bacterial strains used are listed in Table 1. E. coli strains Top10 and BL21 Star (Life Technologies, San Francisco, CA,

Table 1. Strains and plasmids used in this study

\begin{tabular}{|c|c|c|}
\hline Strains/plasmids & Characteristics $^{\mathbf{a}}$ & Source \\
\hline $\begin{array}{l}\text { Xylella fastidiosa subsp. } \\
\text { fastidiosa Stag's Leap }\end{array}$ & Wild-type $X$. fastidiosa, parent strain for mutants & \\
\hline$\Delta \operatorname{cspl}$ & Knockout in PD1380, $\mathrm{Cm}^{\mathrm{R}}$ & This study \\
\hline$\Delta \operatorname{csp} 1 / \operatorname{csp} 1^{+}$ & $\Delta \operatorname{cspl} 1$ complemented by chromosomal insertion of $\operatorname{csp} 1 \mathrm{Cm}^{\mathrm{R}}, \mathrm{Gm}^{\mathrm{R}}$ & This study \\
\hline$\Delta \operatorname{csp} 1 / E \operatorname{ccsp} A^{+}$ & $\Delta \operatorname{csp} 1$ complemented by chromosomal insertion of Escherichia coli $\operatorname{csp} A \mathrm{Cm}^{\mathrm{R}}, \mathrm{Gm}^{\mathrm{R}}$ & This study \\
\hline$\Delta \operatorname{csp} 1 / X \operatorname{ccsp} p^{+}$ & $\begin{array}{l}\Delta \text { cspl complemented by chromosomal insertion of Xanthomonas campestris pv. } \\
\text { campestris } \operatorname{cspA~} \mathrm{Cm}^{\mathrm{R}}, \mathrm{Gm}^{\mathrm{R}}\end{array}$ & This study \\
\hline X. fastidiosa/csp $1^{+}$ & Wild-type Stag's Leap with chromosomal insertion of $X$. fastidiosa cspl, $\mathrm{Gm}^{\mathrm{R}}$ & \\
\hline X. fastidiosa/Eccsp $A^{+}$ & Wild-type Stag's Leap with chromosomal insertion of E. coli $\operatorname{csp} A, \mathrm{Gm}^{\mathrm{R}}$ & This study \\
\hline X. fastidiosa/Xccsp ${ }^{+}$ & Wild-type Stag's Leap with chromosomal insertion of $X$. campestris $\operatorname{csp} A \mathrm{Gm}^{\mathrm{R}}$ & This study \\
\hline Escherichia coli Top 10 & $\begin{array}{l}\text { Cloning host, } \mathrm{F}-m c r A \Delta(m r r-h s d \mathrm{RMS}-m c r \mathrm{BC}), \Phi 80 \text { lacZ } \Delta \mathrm{M} 15, \Delta l a c \mathrm{X} 74, \text { rec } \mathrm{A} 1 \text {, } \\
\text { araD139, } \Delta(\text { araleu }) 7697, \text { gal } \mathrm{U}, \text { gal } \mathrm{K}, \operatorname{rps} \mathrm{L},\left(\mathrm{Str}^{\mathrm{R}}\right), \text { end } \mathrm{A} 1, \text { nup } \mathrm{G}\end{array}$ & Life Technologies \\
\hline Escherichia coli BL21 Star (DE3) & Expression host, $\mathrm{F}^{-}$omp $\mathrm{T}$ hsd $\mathrm{S}_{\mathrm{B}}\left(\mathrm{r}_{\mathrm{B}-}, \mathrm{m}_{\mathrm{B}}\right)$ galdcmrne $131(\mathrm{DE} 3)$ & Life Technologies \\
\hline Xanthomonas campestris 8004 & $\begin{array}{l}\text { Spontaneous rifampicin-resistant strain derived from Xanthomonas campestris pv. } \\
\text { campestris NCPPB No. } 1145\end{array}$ & \\
\hline \multicolumn{3}{|c|}{ 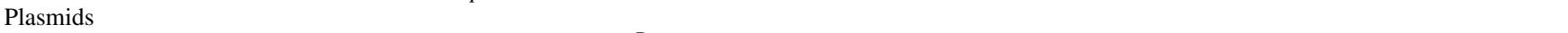 } \\
\hline pCR8/GW/TOPO & TA cloning vector, $\mathrm{Sp}^{\mathrm{R}}$, att sites for Gateway cloning & Life Technologies \\
\hline pET101/D-TOPO & Expression vector, ApR, C-terminal 6xHis tag & Life Technologies \\
\hline pCR8- csp1::chl & csp1::cat cloned into $\mathrm{pCR} 8 / \mathrm{GW} / \mathrm{TOPO}, \mathrm{Sp}^{\mathrm{R}}, \mathrm{Cm}^{\mathrm{R}}$ & This study \\
\hline pCR8-Xfcsp1ORF & X. fastidiosa cspl cloned into $\mathrm{pCR} 8 / \mathrm{GW} / \mathrm{TOPO}, \mathrm{Sp}^{\mathrm{R}}$ & This study \\
\hline pCR8-EccspAORF & E. coli $\operatorname{csp} A$ cloned into $\mathrm{pCR} 8 / \mathrm{GW} / \mathrm{TOPO}, \mathrm{Sp}^{\mathrm{R}}$ & This study \\
\hline pCR8-XccspORF & Xanthomonas campestris pv. campestris cspA cloned into pCR8/GW/TOPO, $\mathrm{Sp}^{\mathrm{R}}$ & This study \\
\hline pAX1-Gm & $\begin{array}{l}\text { Suicide vector for recombination into neutral site } 1 \text { on } X \text {. fastidiosa Temecula } \\
\text { chromosome, } \mathrm{Gm}^{\mathrm{R}}\end{array}$ & Matsumoto et al. 2009 \\
\hline $\mathrm{pAX} 1-\mathrm{Gm} / \mathrm{GW}$ & pAX1-Gm with Gateway cassette & This study \\
\hline pAX1-Xfcsp1 & X. fastidiosa cspl cloned into $\mathrm{pAX} 1-\mathrm{Gm}, \mathrm{Gm}^{\mathrm{R}}$ & This study \\
\hline pAX1-EccspA & E. coli $\operatorname{csp} A$ cloned into $\mathrm{pAX} 1-\mathrm{Gm}, \mathrm{Gm}^{\mathrm{R}}$ & This study \\
\hline pAX1-Xccsp & Xanthomonas campestris pv. campestris cspA cloned into pAX1-Gm, $\mathrm{Gm}^{\mathrm{R}}$ & This study \\
\hline pET101-csp1 & $X$. fastidiosa csp1 cloned into pET101/D-TOPO for inducible expression, Ap $^{\mathrm{R}}$ & This study \\
\hline pGEM-luc & Promoterless firefly luciferase gene $(l u c)$ in pGEM vector, $\mathrm{Ap}^{\mathrm{R}}$ & Promega \\
\hline pCR8-luc & luc cloned into $\mathrm{pCR} 8 / \mathrm{GW} / \mathrm{TOPO}$ & This study \\
\hline pCR8-ECcspA-luc & Reporter construct with E. coli $\operatorname{csp} A-l u c, \mathrm{Sp}^{\mathrm{R}}$ & This study \\
\hline pCR8-Xfcsp1-luc & Reporter construct with $X$. fastidiosa cspl-luc, $\mathrm{Sp}^{\mathrm{R}}$ & This study \\
\hline
\end{tabular}

${ }^{a} \mathrm{Cm}^{\mathrm{R}}, \mathrm{Sp}^{\mathrm{R}}, \mathrm{Ap}^{\mathrm{R}}, \mathrm{Gm}^{\mathrm{R}}$, and $\mathrm{Str}^{\mathrm{R}}$ indicate resistance to chloramphenicol, spectinomycin, ampicillin, gentamycin, and streptomycin, respectively. 
U.S.A.) were used as cloning and protein expression hosts, respectively. E. coli strains were grown in Luria-Bertani medium (LB) at $37^{\circ} \mathrm{C}$, unless otherwise indicated, with the addition of antibiotics when necessary. For $E$. coli, antibiotics were used at the following concentrations $(\mu \mathrm{g} / \mathrm{ml})$ : ampicillin, 100; spectinomycin, 100; kanamycin, 30; chloramphenicol, 35; and gentamycin, 10. X. fastidiosa Stag's Leap wild type and mutant derivatives were grown in PD3 (Davis et al. 1981) medium at $28^{\circ} \mathrm{C}$. For $X$. fastidiosa strains, PD3 was supplemented, when necessary, with kanamycin, gentamycin, or chloramphenicol, at a concentration of $5 \mu \mathrm{g} / \mathrm{ml}$. Xanthomonas campestris pv. campestris 8004 was grown in LB medium at $28^{\circ} \mathrm{C}$.

\section{$\Delta \operatorname{csp} 1$ mutant construction.}

The genome sequence of $X$. fastidiosa Temecula-1 (Van Sluys et al. 2003) was used for reference in the absence of the full genome sequence of the Stag's Leap strain. All primer sequences used for PCR amplification are listed in Table 2. The ORF in Stag's Leap corresponding to Temecula 1 locus tag PD1380 is referred to as cspl. This region (including $1 \mathrm{~kb}$ upstream and downstream) was PCR-amplified, using primers csp1LFfwd and csp1RFrev, and was sequenced prior to mutagenesis. Nucleotide sequence of cspl was $100 \%$ identical to PD1380 of Temecula-1. One-kilobase DNA fragments upstream and downstream of $\operatorname{cspl}$ were PCR-amplified, using Stag's Leap genomic DNA as template and primer pairs csp1LFfwd and csp1LFrevChl and csp1RFfwdChl and csp1RFrev. A chloramphenicol resistance cassette from the Tn5 HyperMu transposon (Epicentre, Madison, WI, U.S.A.) was PCR-amplified separately, using primers Chlfwd and Chlrev. Primers csp1LFrevChl and csp1RFfwdChl contain 15 base pairs of sequence homologous to the chloramphenicol resistance marker. Upstream and downstream flanking regions, and the chloramphenicol resistance marker, were annealed together using overlap extension PCR (Heckman and Pease 2007). The combined PCR product of approximately $3 \mathrm{~kb}$ was gel-purified and cloned into vector $\mathrm{pCR} 8 / \mathrm{GW} / \mathrm{TOPO}$ (Life Technologies), following the manufacturer's instructions, to create pCR8-csp1::chl. This plasmid was transformed into $X$. fastidiosa by electroporation, following the protocol of Guilhabert et al. (2001). Homologous recombination and gene replacement were selected for by plating transformants on PD3 with chloramphenicol. Chloramphenicolresistant colonies were screened by colony PCR, using primer sets RST31 and RST33 (X. fastidiosa-specific primers) and csploutfwd and csploutrev (gene-specific primers). Correct mutants $(\Delta \operatorname{cspl})$ were further confirmed by cloning and sequencing the site of recombination.

\section{Mutant complementation.}

For complementation of mutant $\Delta \operatorname{cspl} 1$, the $\operatorname{cspl}$ ORF and flanking sequences were inserted into a neutral region of the chromosome, as described by Matsumoto et al. (2009). Briefly, cspl with an additional 250bp upstream and downstream (to include all native promoter and terminator sequences) was PCR-amplified, using primers csp1ORFfwd and csp1ORFrev and was cloned into vector pCR8 and GW/TOPO. following the manufacturer's instructions, creating the pCR8-csp1ORF. Chromosomal insertion vector pAX1-Gm (Matsumoto et al. 2009) was modified using the Gateway vector conversion kit (Life Technologies) to create vector pAX1-Gm/GW. The resulting construct (pCR8-csp1ORF) was recombined with pAX1-Gm/GW, using LR clonase enzyme mix (Life Technologies), according to the manufacturer's protocol, to create insertion construct pAX1-Xfcsp1. This plasmid was transformed into $\Delta \operatorname{csp} 1$ by electroporation; recombination into the neutral site was confirmed by cloning and sequencing the site of recombination. This complemented strain was called $\Delta \operatorname{cspl} 1 / \operatorname{csp1^{+}}$.

Strains $\Delta \operatorname{csp} / E \operatorname{ccsp} A^{+}$and $\Delta \operatorname{csp} / X \operatorname{css} p^{+}$were created in a similar manner, except with CSP genes derived from $E$. coli (ECDH10B_3735) or X. campestris pv. campestris (XC_1828).

Table 2. Primer sequences used for polymerase chain reaction amplification

\begin{tabular}{|c|c|c|}
\hline Primer & Sequence & Source or reference \\
\hline RST31 & GCGTTAATTTTCGAAGTGATTCGATTGC & Minsavage et al. 1994 \\
\hline RST33 & CACCATTCGTATCCCGGTG & Minsavage et al. 1994 \\
\hline csp1LFfwd & GTCGCTAGTGGTGCTGATGATTAA & This study \\
\hline csp1LFrevchl & CGATAGGATCCGTGGTGATGCGAGA & This study \\
\hline csp1RFfwdchl & GAAAAGGATCCGTGAAATGTCGCGT & This study \\
\hline csp1RFrev & CACGCTCCCATTCGCATATACA & This study \\
\hline Chlfwd & AACGGATCCTATCGTCAATTATTACCTCCA & This study \\
\hline Chlrev & ACGGATCCTTTTCGACCGAATAAATACC & This study \\
\hline Csp1 ORF fwd & TCTCCAACTGGGCGGC & This study \\
\hline Csp1 ORF rev & TTTTAATGAACACTAGGATGGTTGA & This study \\
\hline ECcspAfwd & GTATCAGTCGCCATGGTAAAGGAA & This study \\
\hline ECcspArev & AAGCAGAGATTACAGGCTGGTTACGTTACC & This study \\
\hline $\begin{array}{l}\text { Xanthomonas campestris } \\
\text { pv. campestris cspA fwd }\end{array}$ & CAAGACCTGGCGGGAGTG & This study \\
\hline $\begin{array}{l}\text { Xanthomonas campestris } \\
\text { pv. campestris } \text { cspA rev }\end{array}$ & TTAGACCGCCTGCACCTG & This study \\
\hline Csplexpfwd & CACCATGCAGAGCGGTACAGTTAAG & This study \\
\hline Csplexprev & TGCTGGCGTGATATTCGATGCTTG & This study \\
\hline csploutfwd & GTTGTTTGGCCAGCGTGTGG & This study \\
\hline csploutrev & GAGCAAGCACTCTTATTACCGACCC & This study \\
\hline Xf145-60F & TACATCGGAATCTACCTTATCGTG & Ledbetter and Rogers 2009 \\
\hline Xf145-60R & ATGCGGTATTTAGCGTAAGTTTC & Ledbetter and Rogers 2009 \\
\hline Xylella fastidiosa RACE 1 & CCCTGCGTCACGTCATAAGT & This study \\
\hline EC RACE 1 & CTTTAGCGCCGCTTTCGATG & This study \\
\hline X. fastidiosa RACE 2 & GGGAGTCCCATCATCCGGTA & This study \\
\hline Escherichia coli RACE 2 & AGAGCCATCGTCAGGAGTGA & This study \\
\hline LucFwd & ATGGAAGACGCCAAAAACATAAAG & This study \\
\hline LucRev & AATTTGGACTTTCCGCCCTTCTTGG & This study \\
\hline Xf5UTRfwd & GTTGCGCGAGAGTGATTGTC & This study \\
\hline XfORFlucrev & ATGTTTTTGGCGTCTTCCATTATTGGCGTGATATTCGATG & This study \\
\hline EC5UTRfwd & CCTGATGACAGGACCGTTTTCCAAC & This study \\
\hline ECORFlucrev & TGTTTTTGGCGTCTTCCATCAGGCTGGTTACGTTACCAGC & This study \\
\hline
\end{tabular}


Both genes were PCR-amplified (including an additional 250bp upstream and downstream) from genomic DNA of E. coli Top 10 or $X$. campestris pv. campestris 8004 , using primer sets ECcspAfwd/ECcspArev or XCcspAfwd/XCcspArev, respectively. The amplification products were cloned into vector pCR8/GW/TOPO to create plasmids pCR8-EccspA and pCR8Xccsp. These plasmids were recombined with insertion vector $\mathrm{pAX} 1-\mathrm{Gm} / \mathrm{GW}$ to create pAX1-EccspA and pAX1-Xccsp. These two plasmid constructs were then transformed into $X$. fastidiosa $\Delta \operatorname{csp} 1$ to create strains $\Delta \operatorname{csp} / E \operatorname{csp} A^{+}$and $\Delta \operatorname{csp} / X \operatorname{css} p^{+}$. Strains $X$. fastidiosa $\operatorname{csp} I^{+}, X$. fastidiosa/Eccsp $A^{+}$, and $X$. fastidiosa/Xcccsp ${ }^{+}$ were created by transforming wild-type $X$. fastidiosa Stag's Leap with insertion vectors pAX1-Xfcsp1, pAX1-EccspA, and pAX1-Xccsp.

\section{Cold tolerance assay.}

$X$. fastidiosa strains were grown on PD3 plates for 7 days at $28^{\circ} \mathrm{C}$. Cells were harvested by scraping off plates and resuspended in sterile $1 \times$ PBS. Starting cell density was normalized by measuring optical density at $600 \mathrm{~nm}\left(\mathrm{OD}_{600}\right)$ and adjusting the concentration to $\mathrm{OD}_{600}=0.1$ with $1 \times$ PBS. A $1-\mathrm{ml}$ aliquot of cells from each strain was removed and serial dilutions were plated on PD3 to serve as an untreated control. Coldtreated samples were kept at $4^{\circ} \mathrm{C}$ for $24 \mathrm{~h}$ and, then, serial dilutions were plated on PD3. CFU were counted for quantification after 7 days of incubation at $28^{\circ} \mathrm{C}$. Percent survival indicates number of colonies in the cold-treated sample divided by number of colonies for the corresponding untreated control. Experiments were repeated at least three times, including a total of at least nine independent biological replicates.

\section{Salt tolerance.}

Cells were grown on PD3 plates for 1 week and were harvested in $1 \times$ PBS. Cell concentration was normalized to $\mathrm{OD}_{600}=$ 0.25 and was divided into $1-\mathrm{ml}$ aliquots. Cells were concentrated by centrifugation, were resuspended in either $1 \times$ PBS (control) or $\mathrm{NaCl}$ at a concentration of $0.3,0.1$, or $0.05 \mathrm{M}$, and were placed on a shaker $(180 \mathrm{rpm})$ for $1 \mathrm{~h}(0.3 \mathrm{M}$ treatment $), 48 \mathrm{~h}(0.1 \mathrm{M}$ treatment), or $72 \mathrm{~h}\left(0.05 \mathrm{M}\right.$ treatment) at $28^{\circ} \mathrm{C}$. After incubation, cells were centrifuged and were washed twice in $1 \times$ PBS to remove salt, and serial dilutions were plated on PD3. CFU were quantified after 10 days of growth at $28^{\circ} \mathrm{C}$. Percent survival was based on number of colonies from salt-treated samples divided by number of colonies for the corresponding untreated control. Experiments were repeated at least three times, including a total of at least nine independent biological replicates.

\section{Hydrogen peroxide sensitivity.}

Hydrogen peroxide sensitivity was quantified using a disc inhibition assay as described by Matsumoto et al. (2009). Cells were grown on PD3 for 1 week at $28^{\circ} \mathrm{C}$, were harvested with PD3 liquid medium, and were normalized to $\mathrm{OD}_{600}=0.1$. Cell suspensions $(500 \mu \mathrm{l})$ were mixed with $5 \mathrm{ml}$ of PD3 top agar $(0.8 \%$ agar) and were spread on PD3 plates. A small paper disc was placed in the center of each plate and was soaked with $10 \mu \mathrm{l}$ of $0.5 \%$ hydrogen peroxide. Zone of inhibition radii were measured after 7 days of growth at $28^{\circ} \mathrm{C}$. Experiments were performed three separate times to include a total of nine biological replicates.

\section{Expression and purification of $X$. fastidiosa Csp1.}

The ORF of $c$ sp 1 , sans stop codon, was PCR-amplified, using primers csplexpfwd and csplexprev, and were cloned into the inducible expression vector pET101/D-TOPO (Life Technologies). Expression clones of pET101-csp1 were screened by sequencing to determine correct orientation and reading frame in relation to the C-terminal $6 x H i s$ tag and to confirm correct sequence. For induced expression, pET101-csp1 was transformed into BL21 Star Competent cells (Life Technologies). Protein expression was induced by addition of $400 \mu \mathrm{M}$ isopropyl- $\beta$-D-thiogalactoside to midlog phase cultures, followed by $4 \mathrm{~h}$ of growth at $37^{\circ} \mathrm{C}$. Cells were harvested by centrifugation and were frozen at $-20^{\circ} \mathrm{C}$. Frozen cell pellets were lysed with B-PER bacterial protein extraction reagent (Life Technologies) with $100 \mu \mathrm{g}$ of lysozyme per milliliter (SigmaAldrich, St. Louis), protease inhibitor cocktail (Sigma-Aldrich), and $4 \mathrm{U}$ of Turbo Dnase per milliliter (Life Technologies) was added. Recombinant Csp1-His was purified from cell lysates using HisPur Ni-NTA columns (Life Technologies) and was eluted with $250 \mu \mathrm{M}$ imidazole (Sigma-Aldrich). Purified protein samples were concentrated by filtration, using Ambion Ultra 0.5 centrifugal filter devices (EMD Millipore, Darmstadt, Germany).

\section{RNA binding assay.}

Plasmid pCR8/GW/TOPO, linearized with EcoRI (New England Biolabs, Ipswitch, MA, U.S.A.), was used as a template for in vitro transcription of biotin labeled RNA probes (150 nt), using AmpliScribe T7 Biotin-RNA kit (Epicentre). Transcribed RNA was purified by phenol-chloroform extraction and ethanol precipitation. Binding assays were performed in $10 \mu \mathrm{l}$ of binding buffer (Jiang et al. 1997) containing $10 \mathrm{mM}$ Tris-HCl (pH 8.0), $1 \mathrm{mM}$ EDTA, $50 \mathrm{mM} \mathrm{KCl}$, and 7.4\% glycerol. Binding reactions contained 20 ng RNA and increasing concentrations of purified Csp1-His $(1,3$, and $5 \mu \mathrm{g}$ ). Bovine serum albumin (SigmaAldrich) was used as a nonbinding protein control (5 or $10 \mu \mathrm{g})$. After $10 \mathrm{~min}$ of incubation at room temperature, samples were electrophoresed on a $5 \%$ acrylamide gel in $0.5 \times$ tris-borateEDTA at $200 \mathrm{~V}$ for $35 \mathrm{~min}$ and were transferred to a Biodyne B positively charged nylon membrane (Life Technologies). Following transfer, blots were placed face down on a $302 \mathrm{~nm} \mathrm{UV}$ transilluminator for 2 min for cross-linking. RNA detection was carried out using the Chemiluminescent detection module (Life Technologies), with imaging on a FluorChem E CCD imager (ProteinSimple, San Jose, CA, U.S.A.).

\section{Sequencing of $5^{\prime}$ UTR.}

Total RNA was extracted from $X$. fastidiosa cultures grown on PD3 plates for 6 days at $28^{\circ} \mathrm{C}$ and from E. coli cultures grown on LB overnight at $37^{\circ} \mathrm{C}$. RNA extraction was done following the protocol by Jahn et al. (2008). RNA samples were treated with Turbo Dnase (Life Technologies), following the manufacturer's protocol to remove trace genomic DNA. Total RNA $(1 \mu \mathrm{g})$ was used as template for 5' RACE (Scotto-Lavino et al. 2007), using the 5' RACE system kit (Life Technologies), with primers specific for $c s p l$ of $X$. fastidiosa (XfRACE1) or $\operatorname{csp} A$ of $E$. coli (ECRACE1), for the respective RNA samples. Products were PCR-amplified using primers XfRACE2 or ECRACE2 along with Abridged Anchor Primer, provided as part of the kit. PCR products were gel-purified and were cloned into $\mathrm{pCR} 8 / \mathrm{GW} / \mathrm{TOPO}$ for sequencing.

\section{Luciferase reporter assay.}

Reporter constructs were made with a promoterless firefly luciferase gene cloned from pGem-luc (Promega, Madison, WI, U.S.A.). The luc ORF was PCR-amplified using primers Lucfwd and Lucrev. This DNA fragment was cloned into pCR8/GW/TOPO to serve as a promoterless control for the reporter assays (pCR8-luc). DNA fragments consisting of the promoter, $5^{\prime}$ UTR, and ORF (without a stop codon) of $X$. fastidiosa cspl and E. coli cspA were PCR-amplified using primer sets Xf5UTRfwd and XfORFlucrev and EC5UTRfwd and ECORFlucrev, respectively. These fragments were then attached to the luc PCR product using overlap extension PCR and were cloned into pCR8/GW/TOPO, creating reporter fusion constructs pCR8-Xfcspl-luc and pCR8-EccspA-luc. 
All three plasmids were transformed into E. coli Top10 for propagation. Reporter strains were grown at $37^{\circ} \mathrm{C}$ until reaching a cell density of $\mathrm{OD}_{600}=0.5 ; 1-\mathrm{ml}$ aliquots were removed for untreated controls. Cold-treated samples were incubated at $15^{\circ} \mathrm{C}$ on a shaker for up to $2 \mathrm{~h}$. All samples were harvested by centrifugation and were lysed in $300 \mu \mathrm{l}$ of B-Per bacterial protein extraction reagent, as described for Csp1-His purification. Total protein $(1 \mu \mathrm{g})$ from each sample was used for sodium dodecyl sulfatepolyacrylamide gel electrophoresis and Western blotting with firefly luciferase monoclonal antibody (mouse-Luc17) (Life Technologies). Blots were developed with Pierce SuperSignal West Pico chemiluminescent substrate (Life Technologies) and were imaged with FluorChem E CCD imager (ProteinSimple).

\section{Virulence assays.}

Grapevines (Vitis vinifera $\mathrm{cv}$. Chardonnay) were inoculated with wild-type Stag's Leap, $\Delta c s p l$, and $\Delta c s p / c s p^{+}$, using the method by Roper et al. (2007). Plants (20 plants per treatment) were observed for symptom development weekly and were assigned a disease rating (0 to 5) based on the system by Roper et al. (2007). Bacterial titer was determined by qPCR at 12 weeks postinoculation. Total DNA was extracted from grapevine petioles $15 \mathrm{~cm}$ above the point of inoculation. qPCR was performed using AB SYBR Green master mix (Life Technologies) following the manufacturer's instructions, with $5 \mu \mathrm{l}$ of total DNA as template and primer set XF145-60fwd and XF145-60rev (Ledbetter and Rogers 2009). Titer of $X$. fastidiosa was determined based on a standard curve of wild-type Stag's Leap genomic DNA, normalized to total DNA concentration. For cold treatment of inoculated vines, plants after 12 weeks postinoculation were pruned back to a single cane about 2 feet long and were separated into two treatment groups (20 plants per strain of each treatment). Plants in the control group remained in the greenhouse at or above $25^{\circ} \mathrm{C}$ and cold-treated vines were place in a cold chamber at $4^{\circ} \mathrm{C}$. Both treatments were under reduced light conditions to promote dormancy. After 6 weeks of cold treatment, all vines were returned to the greenhouse and put under a 10-h daylight cycle to grow out. After 6 weeks of regrowth, bacterial titer was determined by qPCR as described above.

\section{Tests for statistical significance.}

Significance of quantitative differences among treatments (Figs. 2, 3, 7, and 8) was determined using one way analysis of variance followed by a Tukey-Kramer multiple comparison test $(\alpha=0.05)$. All statistical analyses were performed using Origin 2015 graphing and analysis software (OriginLab Inc., Northampton, MA, U.S.A.).

\section{ACKNOWLEDGMENTS}

We thank K. Zhang for technical support and M. S. Sisterson for statistical analysis. Funding for this work was from United State Department of Agriculture (USDA) Agricultural Research Service appropriated project 2034-22000-010-00D. Mention of trade names or commercial products in this publication is solely for the purpose of providing specific information and does not constitute endorsement by USDA. USDA is an equal opportunity provider and employer.

\section{LITERATURE CITED}

Bae, W., Xia, B., Inouye, M., and Severinov, K. 2000. Escherichia coli CspA-family RNA chaperones are transcription antiterminators. Proc. Natl. Acad. Sci. U.S.A. 97:7784-7789.

Balhesteros, H., Mazzon, R., da Silva, C. P. T., Lang, E. S., and Marques, M. 2010. CspC and CspD are essential for Caulobacter crescentus stationary phase survival. Arch. Microbiol. 192:747-758.

Barceló, A. R. 1998. Hydrogen peroxide production is a general property of the lignifying xylem from vascular plants. Ann. Bot. (Lond.) 82:97-103.

Breaker, R. R. 2010. RNA switches out in the cold. Mol. Cell 37:1-2.
Budde, I. P., Rohde, B. H., Bender, C. L., and Ullrich, M. S. 1998. Growth phase and temperature influence promoter activity, transcript abundance, and protein stability during biosynthesis of the Pseudomonas syringae phytotoxin coronatine. J. Bacteriol. 180:1360-1367.

Burbank, L., and Roper, M. C. 2014. OxyR and SoxR modulate the inducible oxidative stress response and are implicated during different stages of infection for the bacterial phytopathogen Pantoea stewartii subsp. stewartii. Mol. Plant-Microbe Interact 27:479-490.

Cao-Hoang, L., Dumont, F., Marechal, P. A., and Gervais, P. 2010 Inactivation of Escherichia coli and Lactobacillus plantarum in relation to membrane permeabilization due to rapid chilling followed by cold storage. Arch. Microbiol. 192:299-305.

Chattopadhyay, M. K., Raghu, G., Sharma, Y. V. R. K., Biju, A. R. Rajasekharan, M. V., and Shivaji, S. 2011. Increase in oxidative stress at low temperature in an antarctic bacterium. Curr. Microbiol. 62:544-546.

Chinnusamy, V., Zhu, J.-K., and Sunkar, R. 2010. Gene regulation during cold stress acclimation in plants. Methods Mol. Biol. 639:39-55.

Cohen-Or, I., Shenhar, Y., Biran, D., and Ron, E. Z. 2010. CspC regulates rpoS transcript levels and complements $h f q$ deletions. Res. Microbiol. 161:694-700

Davis, M., French, W., and Schaad, N. 1981. Axenic culture of the bacteria associated with phony disease of peach and plum leaf scald. Curr. Microbiol. 6:309-314.

Dehal, P. S., Joachimiak, M. P., Price, M. N., Bates, J. T., Baumohl, J. K., Chivian, D., Friedland, G. D., Huang, K. H., Keller, K., Novichkov, P. S., Dubchak, I. L., Alm, E. J., and Arkin, A. P. 2010. MicrobesOnline: An integrated portal for comparative and functional genomics. Nucleic Acids Res. 38:D396-D400.

Derman, Y., Söderholm, H., Lindström, M., and Korkeala, H. 2015. Role of csp genes in $\mathrm{NaCl}, \mathrm{pH}$, and ethanol stress response and motility in Clostridium botulinum ATCC 3502. Food Microbiol. 46:463-470.

Erova, T. E., Kosykh, V. G., Fadl, A. A., Sha, J., Horneman, A. J., and Chopra, A. K. 2008. Cold shock exoribonuclease R (vacB) is involved in Aeromonas hydrophila pathogenesis. J. Bacteriol. 190:3467-3474.

Etchegaray, J.-P., and Inouye, M. 1999. CspA, CspB, and CspG, major cold shock proteins of Escherichia coli, are induced at low temperature under conditions that completely block protein synthesis. J. Bacteriol. 181: 1827-1830.

Feil, H., and Purcell, A. H. 2001. Temperature-dependent growth and survival of Xylella fastidiosa in vitro and in potted grapevines. Plant Dis. 85:1230-1234.

Flores-Cruz, Z., and Allen, C. 2011. Necessity of OxyR for the hydrogen peroxide stress response and full virulence in Ralstonia solanacearum. Appl. Environ. Microbiol. 77:6426-6432.

Fones, H., and Preston, G. M. 2012. Reactive oxygen and oxidative stress tolerance in plant pathogenic Pseudomonas. FEMS Microbiol. Lett. 327:1-8

Giuliodori, A. M., Di Pietro, F., Marzi, S., Masquida, B., Wagner, R., Romby, P., Gualerzi, C. O., and Pon, C. L. 2010. The $\operatorname{cspA}$ mRNA is a thermosensor that modulates translation of the cold-shock protein CspA. Mol. Cell 37:21-33.

Goldstein, J., Pollitt, N. S., and Inouye, M. 1990. Major cold shock protein of Escherichia coli. Proc. Natl. Acad. Sci. U.S.A. 87:283-287.

Graumann, P. L., and Marahiel, M. A. 1998. A superfamily of proteins that contain the cold-shock domain. Trends Biochem. Sci. 23:286-290.

Graumann, P., Schröder, K., Schmid, R., and Marahiel, M. A. 1996. Cold shock stress-induced proteins in Bacillus subtilis. J. Bacteriol. 178:46114619 .

Graumann, P., Wendrich, T. M., Weber, M. H. W., Schröder, K., and Marahiel, M. A. 1997. A family of cold shock proteins in Bacillus subtilis is essential for cellular growth and for efficient protein synthesis at optimal and low temperatures. Mol. Microbiol. 25:741-756.

Guilhabert, M. R., and Kirkpatrick, B. C. 2005. Identification of Xylella fastidiosa antivirulence genes: Hemagglutinin adhesins contribute to $X$. fastidiosa biofilm maturation and colonization and attenuate virulence. Mol. Plant-Microbe Interact 18:856-868.

Guilhabert, M. R., Hoffman, L. M., Mills, D. A., and Kirkpatrick, B. C. 2001. Transposon mutagenesis of Xylella fastidiosa by electroporation of Tn5 synaptic complexes. Mol. Plant-Microbe Interact 14:701-706.

Heckman, K. L., and Pease, L. R. 2007. Gene splicing and mutagenesis by PCR-driven overlap extension. Nat. Protoc. 2:924-932.

Hopkins, D. L., and Purcell, A. H. 2002. Xylella fastidiosa: Cause of Pierce's disease of grapevine and other emergent diseases. Plant Dis. 86:1056-1066.

Jahn, C. E., Charkowski, A. O., and Willis, D. K. 2008. Evaluation of isolation methods and RNA integrity for bacterial RNA quantification J. Microbiol. Methods 75:318-324.

Janiyani, K. L., and Ray, M. K. 2002. Cloning, sequencing, and expression of the cold-inducible hut $U$ gene from the antarctic psychrotrophic bacterium Pseudomonas syringae. Appl. Environ. Microbiol. 68:1-10. 
Jiang, W., Fang, L., and Inouye, M. 1996. The role of the 5'-end untranslated region of the mRNA for CspA, the major cold-shock protein of Escherichia coli, in cold-shock adaptation. J. Bacteriol. 178:4919-4925.

Jiang, W., Hou, Y., and Inouye, M. 1997. CspA, the major cold-shock protein of Escherichia coli, is an RNA chaperone. J. Biol. Chem. 272:196-202.

Kaan, T., Jürgen, B., and Schweder, T. 1999. Regulation of the expression of the cold shock proteins CspB and CspC in Bacillus subtilis. Mol. Gen. Genet. 262:351-354.

Kandror, O., DeLeon, A., and Goldberg, A. L. 2002. Trehalose synthesis is induced upon exposure of Escherichia coli to cold and is essential for viability at low temperatures. Proc. Natl. Acad. Sci. U.S.A. 99:9727-9732.

Kim, B. H., Bang, I. S., Lee, S. Y., Hong, S. K., Bang, S. H., Lee, I. S., and Park, Y. K. 2001. Expression of $c s p H$, encoding the cold shock protein in Salmonella enterica serovar typhimurium UK-1. J. Bacteriol. 183:5580-5588.

Kim, M.-H., Sato, S., Sasaki, K., Saburi, W., Matsui, H., and Imai, R. 2013. COLD SHOCK DOMAIN PROTEIN 3 is involved in salt and drought stress tolerance in Arabidopsis. FEBS Open Bio 3:438-442.

Koide, T., Ricardo, Z. N., Vêncio, R. Z. N., and Gomes, S. L. 2006. Global gene expression analysis of the heat shock response in the phytopathogen Xylella fastidiosa. J. Bacteriol. 188:5821-5830.

Król, A., Amarowiczb, R., and Weidnera, S. 2015. The effects of cold stress on the phenolic compounds and antioxidant capacity of grapevine (Vitis vinifera L.) leaves. J. Plant Physiol. 189:97-104.

Lamb, C., and Dixon, R. A. 1997. The oxidative stress response in plant disease resistance. Annu. Rev. Plant Physiol. Plant Mol. Biol. 48:251-275.

Ledbetter, C. A., and Rogers, E. E. 2009. Differential susceptibility of Prunus germplasm (subgenus Amygdalus) to a California isolate of Xylella fastidiosa. HortScience 44:1928-1931.

Lee, S. J., Xie, A., Jiang, W., Etchegaray, J.-P., Jones, P. G., and Inouye, M. 1994. Family of the major cold-shock protein, CspA (CS7.4), of Escherichia coli, whose members show a high sequence similarity with the eukaryotic Y-box binding proteins. Mol. Microbiol. 11:833-839.

Lieth, J. H., Meyer, M. M., Yeo, K. H., and Kirkpatrick, B. C. 2011. Modeling cold curing of Pierce's Disease in Vitis vinifera 'Pinot Noir' and 'Cabernet Sauvignon' grapevines in California. Phytopathology 101:1492-1500.

Loepfe, C., Raimann, E., Stephan, R., and Tasara, T. 2010. Reduced host cell invasiveness and oxidative stress tolerance in double and triple csp gene family deletion mutants of Listeria monocytogenes. Foodborne Pathog. Dis. 7:775-783.

Marchler-Bauer, A., Zheng, C., Chitsaz, F., Derbyshire, M. K., Geer, L. Y., Geer, R. C., Gonzales, N. R., Gwadz, M., Hurwitz, D. I., Lanczycki, C. J., Lu, F., Lu, S., Marchler, G. H., Song, J. S., Thanki, N., Yamashita, R. A., Zhang, D., and Bryant, S. H. 2013. CDD: Conserved domains and protein three-dimensional structure. Nucleic Acids Res. 41:D348-D352.

Matsumoto, A., Young, G. M., and Igo, M. M. 2009. Chromosome-based genetic complementation system for Xylella fastidiosa. Appl. Environ. Microbiol. 75:1679-1687.

Meyer, M. M. 2010. The effects of cold temperature on Xylella fastidiosainfected Vitis vinifera grapevines. University of California, Davis.

Meyer, M. M., and Kirkpatrick, B. C. 2011. Exogenous applications of abscisic acid increase curing of Pierce's disease-affected grapevines growing in pots. Plant Dis. 95:173-177.

Michaux, C., Martini, C., Shioya, K., Ahmed Lecheheb, S., Budin-Verneuil, A. Cosette, P., Sanguinetti, M., Hartke, A., Verneuil, N., and Giard, J.-C. 2012. CspR, a cold shock RNA-binding protein involved in the long-term survival and the virulence of Enterococcus faecalis. J. Bacteriol. 194:6900-6908.

Minsavage, G. V., Thomson, C. M., Hopkins, D. L., Leite, R. M. V. B. C., and Stall, R. E. 1994. Development of a polymerase chain reaction protocol for detection of Xylella fastidiosa in plant tissue. Phytopathology 84:456-461.

Mitta, M., Fang, L., and Inouye, M. 1997. Deletion analysis of $\operatorname{cspA}$ of Escherichia coli: Requirement of the AT-rich UP element for $c s p A$ transcription and the downstream box in the coding region for its cold shock induction. Mol. Microbiol. 26:321-335.

Nakaminami, K., Karlson, D. T., and Imai, R. 2006. Functional conservation of cold shock domains in bacteria and higher plants. Proc. Natl. Acad. Sci. U.S.A. 103:10122-10127.

Nakashima, K., Kanamaru, K., Mizuno, T., and Horikoshi, K. 1996. A novel member of the $\operatorname{csp} A$ family of genes that is induced by cold shock in Escherichia coli. J. Bacteriol. 178:2994-2997.

Phadtare, S. 2011. Unwinding activity of cold shock proteins and RNA metabolism. RNA Biol. 8:394-397.

Phadtare, S., and Inouye, M. 2001. Role of CspC and CspE in regulation of expression of RpoS and UspA, the stress response proteins in Escherichia coli. J. Bacteriol. 183:1205-1214.

Phadtare, S., and Severinov, K. 2010. RNA remodeling and gene regulation by cold shock proteins. RNA Biol. 7:788-795.

Purcell, A. H., Saunders, S. R., Hendson, M., Grebus, M. E., and Henry, M. J. 1999. causal role of Xylella fastidiosa in oleander leaf scorch disease. Phytopathology 89:53-58.
Roper, M. C., Greve, L. C., Warren, J. G., Labavitch, J. M., and Kirkpatrick, B. C. 2007. Xylella fastidiosa requires polygalacturonase for colonization and pathogenicity in Vitis vinifera grapevines. Mol. Plant-Microbe Interct. 20:411-419.

Schindelin, H., Marahiel, M. A., and Heinemann, U. 1993. Universal nucleic acid-binding domain revealed by crystal structure of the B. subtilis major cold-shock protein. Nature 364:164-168.

Schmid, B., Klumpp, J., Raimann, E., Loessner, M. J., Stephan, R., and Tasara, T. 2009. Role of cold shock proteins in growth of Listeria monocytogenes under cold and osmotic stress conditions. Appl. Environ. Microbiol. 75:1621-1627.

Schröder, K., Graumann, P., Schnuchel, A., Holak, T. A., and Marahiel, M. A. 1995. Mutational analysis of the putative nucleic acid-binding surface of the cold-shock domain, CspB, revealed an essential role of aromatic and basic residues in binding of single-stranded DNA containing the Y-box motif. Mol. Microbiol. 16:699-708.

Scotto-Lavino, E., Du, G., and Frohman, M. A. 2007. 5' end cDNA amplification using classic RACE. Nat. Protoc. 1:2555-2562.

Shenhar, Y., Biran, D., and Ron, E. Z. 2012. Resistance to environmental stress requires the RNA chaperones CspC and CspE. Environ. Microbiol. Rep. 4:532-539.

Sievers, F., Wilm, A., Dineen, D., Gibson, T. J., Karplus, K., Li, W., Lopez, R., McWilliam, H., Remmert, M., Söding, J., Thompson, J. D., and Higgins, D. G. 2011. Fast, scalable generation of high-quality protein multiple sequence alignments using Clustal Omega. Mol. Syst. Biol. 7:539.

Smirnova, A., Li, H., Weingart, H., Aufhammer, S., Burse, A., Finis, K., Schenk, A., and Ullrich, M. 2001. Thermoregulated expression of virulence factors in plant-associated bacteria. Arch. Microbiol. 176:393-399.

Söderholm, H., Lindström, M., Somervuo, P., Heap, J., Minton, N., Lindén, J., and Korkeala, H. 2011. $\operatorname{cspB}$ encodes a major cold shock protein in Clostridium botulinum ATCC 3502. Int. J. Food Microbiol. 146:23-30.

Uppal, S., Rao Akkipeddi, V. S. N., and Jawali, N. 2008. Posttranscriptional regulation of $\operatorname{ssp} E$ in Escherichia coli: Involvement of the short 5'-untranslated region. FEMS Microbiol. Lett. 279:83-91.

Van Sluys, M. A., de Oliveira, M. C., Monteiro-Vitorello, C. B., Miyaki, C. Y., Furlan, L. R., Camargo, L. E. A., da Silva, A. C. R., Moon, D. H., Takita, M. A., Lemos, E. G. M., Machado, M. A., Ferro, M. I. T., da Silva, F. R., Goldman, M. H. S., Goldman, G. H., Lemos, M. V. F., El-Dorry, H., Tsai, S. M., Carrer, H., Carraro, D. M., de Oliveira, R. C., Nunes, L. R., Siqueira, W. J., Coutinho, L. L., Kimura, E. T., Ferro, E. S., Harakava, R., Kuramae, E. E., Marino, C. L., Giglioti, E., Abreu, I. L., Alves, L. M. C., do Amaral, A. M., Baia, G. S., Blanco, S. R., Brito, M. S., Cannavan, F. S., Celestino, A. V., da Cunha, A. F., Fenille, R. C., Ferro, J. A., Formighieri, E. F., Kishi, L. T., Leoni, S. G., Oliveira, A. R., Rosa, V. E., Jr., Sassaki, F. T., Sena, J. A. D., de Souza, A. A., Truffi, D. Tsukumo, F., Yanai, G. M., Zaros, L. G., Civerolo, E. L., Simpson, A. J. G., Almeida, N. F., Jr., Setubal, J. C., and Kitajima, J. P. 2003 Comparative analyses of the complete genome sequences of Pierce's Disease and citrus variegated chlorosis strains of Xylella fastidiosa. J. Bacteriol. 185:1018-1026.

Wang, N., Yamanaka, K., and Inouye, M. 1999. CspI, the ninth member of the CspA family of Escherichia coli, is induced upon cold shock. J. Bacteriol. 181:1603-1609.

Wang, Z., Wang, S., and Wu, Q. 2014. Cold shock protein A plays an important role in the stress adaptation and virulence of Brucella melitensis. FEMS Microbiol. Lett. 354:27-36.

Weber, M. H. W., Fricke, I., Doll, N., and Marahiel, M. A. 2002. CSDBase: An interactive database for cold shock domain-containing proteins and the bacterial cold shock response. Nucleic Acids Res. 30:375-378.

Wei, Z. M., Sneath, B. J., and Beer, S. V. 1992. Expression of Erwinia amylovora hrp genes in response to environmental stimuli. J. Bacteriol. 174:1875-1882.

Wilhelm, M., Brodbeck, B. V., Andersen, P. C., Kasun, G. W., and Kirkpatrick, B. C. 2011. Analysis of xylem fluid components in almond cultivars differing in resistance to almond leaf scorch disease. Plant Dis. 95:166-172.

Wise, R. 1995. Chilling-enhanced photooxidation: The production, action and study of reactive oxygen species produced during chilling in the light. Photosynth. Res. 45:79-97.

Xia, B., Ke, H., and Inouye, M. 2001. Acquirement of cold sensitivity by quadruple deletion of the $\operatorname{cspA}$ family and its suppression by PNPase S1 domain in Escherichia coli. Mol. Microbiol. 40:179-188.

Yamanaka, K., and Inouye, M. 1997. Growth-phase-dependent expression of cspD, encoding a member of the CspA family in Escherichia coli. J. Bacteriol. 179:5126-5130.

Yamanaka, K., Fang, L., and Inouye, M. 1998. The CspA family in Escherichia coli: Multiple gene duplication for stress adaptation. Mol Microbiol. 27:247-255. 